\title{
THE RATE OF ABSORPTION AND EXCRETION OF THE, IODIDS OF STRONTIUM, SODIUM AND POTASSIUM *
}

\author{
E. J. KRAHULIK, M.D., AND J. D. PILCHER, M.D. \\ OMAHA \\ Cleveland
}

Strontium salts have been used to a limited extent in therapeutics for the effect of the bromid, iodid or salicylate radical, but their use has been more or less discouraged because it was thought that the strontium salts were more slowly absorbed than the corresponding salts of sodium and potassium. ${ }^{1}$

Since all iodids would exist in the blood and tissues essentially as sodium iodid, the excretion would be the same irrespective of the cathion, provided, of course, that the other conditions were the same. Consequently, any difference in the excretion of the iodid in the urine would indicate that the change was primarily in the absorption of the original iodid. Iodid was chosen in this investigation because its normal excretion has often been determined and because its quantitative estimation is simple and accurate. The excretion of strontium iodid was compared with that of sodium and potassium.

Method.-The investigation was made chiefly on one subject, but for comparison a lesser number of experiments were made with the strontium and sodium salts, only, on two other individuals. Each subject led a fairly uniform life during the investigation. The iodid was taken immediately after a uniform breakfast and the total urine collected at the following periods: $1 / 2,1,2,6,12,24,48$ and 72 hours. At least three experiments were made with each drug, with a minimum interval of four days between experiments to insure the complete excretion of the previous dose. The iodid was estimated by the usual methods. ${ }^{2}$ The averages of the iodid excreted at the different periods

\footnotetext{
* Submitted for publication July 31, 1917.

* From the Pharmacological Laboratory, School of Medicine, University of Nebraska.

* The investigation was undertaken at the request of the Committee on Therapeutic Research of the Council on Pharmacy and Chemistry of the American Medical Association.

1. Cushny: Pharmacology and Therapeutics, 1915, p. 567.

2. Convenient quantities of urine (10 to 50 c.c.) were evaporated in nickel crucibles with $1 \mathrm{gm}$. potassium hydroxid and $0.5 \mathrm{gm}$. potassium nitrate per 10 c.c. of urine; fused and dissolved in water; made acid with 10 per cent. sulphuric acid and 10 drops of 10 per cent. sodium nitrite added, and the liberated iodin extracted with carbon disulphid and titrated with hundredth normal thiosulphate.
} 
and the total excretion are given in Table 1 ; the percentages in Table 2. The results are graphically illustrated in Figures 1 and 2. (As the results were similar in the different subjects the excretion of one, only, is given in the figures.)

The iodid content of the salts as determined by analysis was as follows :

$$
\begin{aligned}
& \mathrm{NaI}-0.784 \mathrm{gm} . \text { per } \mathrm{gm} . \\
& \mathrm{SrI}-0.525 \mathrm{gm} . \text { per gm. } \\
& \mathrm{KI}-0.722 \mathrm{gm} . \text { per gm. }
\end{aligned}
$$

\begin{tabular}{|c|c|c|c|c|c|c|c|c|c|c|c|c|}
\hline Hour & $\underset{1 \mathrm{Gm}}{\mathrm{NaI}}$ & Total & $\begin{array}{c}\text { SrI } \\
1 \text { Gm. } \\
\text { (x } \\
\text { Fac- } \\
\text { tor) }\end{array}$ & Total & $\begin{array}{c}\mathrm{SrI} \\
1.5 \mathrm{Gm} .\end{array}$ & Total & $\begin{array}{c}\mathrm{KI} \\
1.09 \\
\mathbf{G m} .\end{array}$ & Total & $\begin{array}{c}\mathrm{NaI}^{*} \\
1 \mathrm{Gm} .\end{array}$ & Total & $\begin{array}{l}\mathrm{SrI}^{*} \\
1 \mathrm{Gm} . \\
(\mathrm{x} \\
\mathrm{Fac}- \\
\text { tor })\end{array}$ & Tota] \\
\hline $1 / 2$ & 0.0063 & & 0.0057 & & 0.0053 & & 0.0082 & & & & & \\
\hline I & $\cdots \cdots$ & ...... & ....... & $\ldots \ldots$ & ...... & $\ldots \ldots$ & $\cdots \cdots$ & $\ldots$. & 0.0298 & 0.0298 & 0.0291 & 0.0291 \\
\hline 2 & 0.0871 & 0.0934 & 0.0816 & 0.0873 & 0.1108 & 0.1156 & 0.1022 & 0.1104 & 0.0581 & 0.0879 & 0.0897 & $0.11 z 8$ \\
\hline 6 & $\underbrace{0.2023}$ & 0.2957 & 0.2116 & 0.2989 & 0.2181 & 0.3336 & 0.2197 & 0.3301 & 0.2182 & 0.3061 & 0.2175 & 0.3363 \\
\hline 12 & 0.1562 & 0.4519 & 0.1748 & 0.4737 & 0.1791 & 0.5126 & 0.1705 & 0.5006 & 0.1700 & 0.4765 & 0.1400 & 0.4763 \\
\hline 24 & 0.1524 & 0.6043 & 0.1268 & 0.6005 & 0.1731 & 0.6858 & 0.1545 & 0.6551 & 0.1288 & 0.6058 & 0.1753 & 0.6518 \\
\hline 48 & 0.0771 & 0.6813 & 0.0942 & 0.6948 & 0.0861 & 0.7719 & 0.0796 & 0.7347 & 0.0542 & 0.6595 & $0.054 n$ & 0.7056 \\
\hline 72 & $\left.\right|^{0.0108}$ & 0.6921 & 0.0130 & 0.7078 & 0.0162 & 0.7881 & 0.0239 & 0.7586 & & & & \\
\hline
\end{tabular}

Table 1.-Quantity of Iodin in the Urine at the Separate Periods, and Total Excretion in Grams of Iodin

* Subject P.; all others from Subject $\mathbf{K}$.

TABLE 2.-Average Total Iodin Excretion in Percentage of the INTAKE IN GRAMS OF IODIN

\begin{tabular}{c|c|c|c|c|c|c}
\hline Hour & $\begin{array}{c}\text { NaI } \\
1 \mathrm{Gm} .\end{array}$ & $\begin{array}{c}\mathrm{SrI} \\
1 \mathrm{Gm} .\end{array}$ & $\begin{array}{c}\mathrm{SrI} \\
1.5 \mathrm{Gm} .\end{array}$ & $\begin{array}{c}\mathrm{KI} \\
1 \mathrm{Gm} .\end{array}$ & $\begin{array}{c}\mathrm{NaI} \\
1 \mathrm{Gm} .\end{array}$ & $\begin{array}{r}\mathrm{SrI}^{*} \\
1 \mathrm{Gm} .\end{array}$ \\
\hline $1 / 2$ & 0.8 & 0.72 & 0.68 & 1.0 & & \\
1 & $\ldots$. & $\ldots$. & $\ldots$. & $\ldots$. & 3.8 & 3.7 \\
2 & 11.8 & 11.1 & 14.7 & 14.1 & 11.2 & 15.2 \\
6 & 37.7 & 38.0 & 42.5 & 42.1 & 39.0 & 12.6 \\
12 & 57.6 & 60.1 & 65.4 & 63.8 & 60.8 & 60.8 \\
24 & 72.8 & 76.5 & 87.5 & 83.5 & 77.2 & 82.8 \\
48 & 82.6 & 88.4 & 98.4 & 93.7 & 84.1 & 90.0 \\
72 & 88.8 & 90.3 & $100+$ & 96.7 & & \\
\hline
\end{tabular}

* Subject. P., all others are from Subject $\mathbf{K}$. 
One gram of sodium iodid was the standard dose; $1.5 \mathrm{gm}$. of strontium iodid and $1.09 \mathrm{gm}$. of potassium iodid gave equal amounts of iodin. In several experiments but $1 \mathrm{gm}$. of strontium iodid was taken, so that in the tables and figures the results are multiplied by the correct factor as indicated.

Rate of Excretion.-There is practically no difference in the rate of excretion of the iodids of strontium, sodium and potassium as illustrated in Figure 1, which shows an increasing excretion rate reaching the maximum at about the sixth hour and then decreasing rapidly; during the third day but 10 to $20 \mathrm{mg}$. were excreted in all.

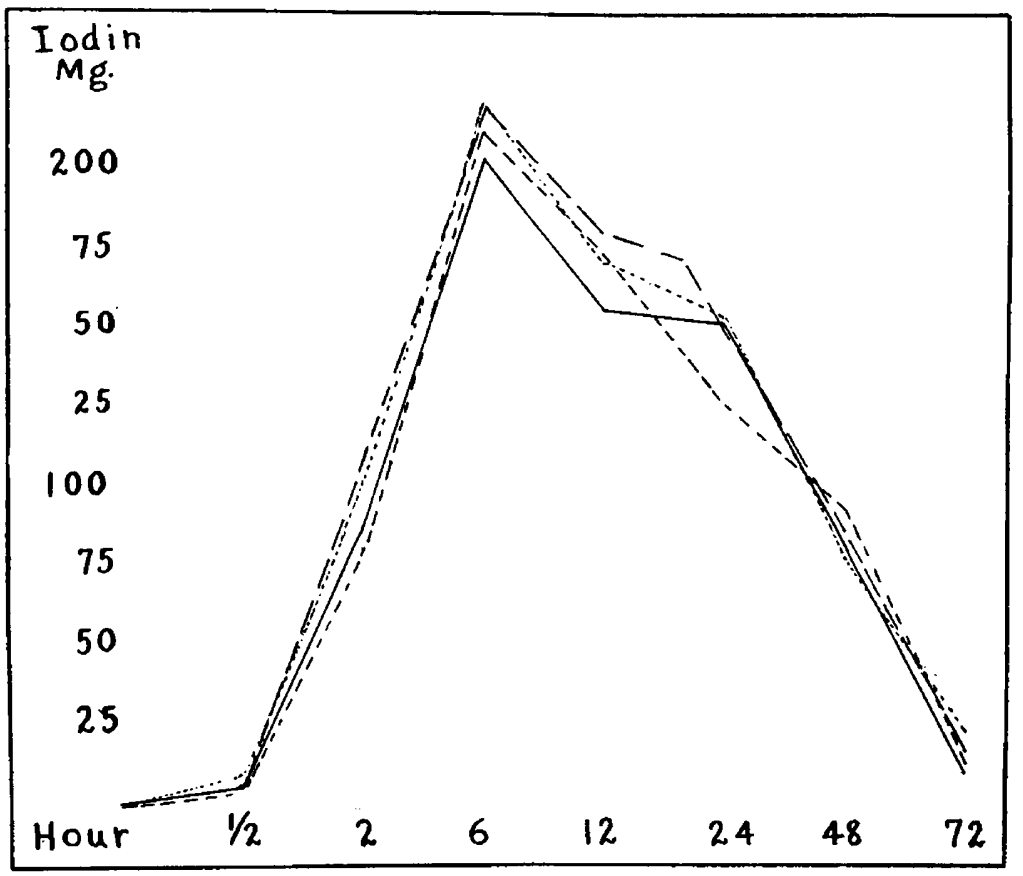

Fig. 1.--Rate of excretion of iodin in milligrams (Subject $\mathrm{K}$ ) ; sodium iodid ; ........ potassium iodid; --- strontium iodid; ....... strontium iodid $\mathrm{x}$ factor.

Total Excretion.-A somewhat greater quantity of the strontium iodid than of the sodium iodid was excreted at the twenty-four, fortyeight and seventy-two hour periods; the potassium iodid (one subject) excretion lay between the strontium series. As can be seen from the tables and figures, the difference is slight and probably of no significance.

There seemed to be no definite ratio between the excretion of the iodid and the volume of urine. There were instances in which a 


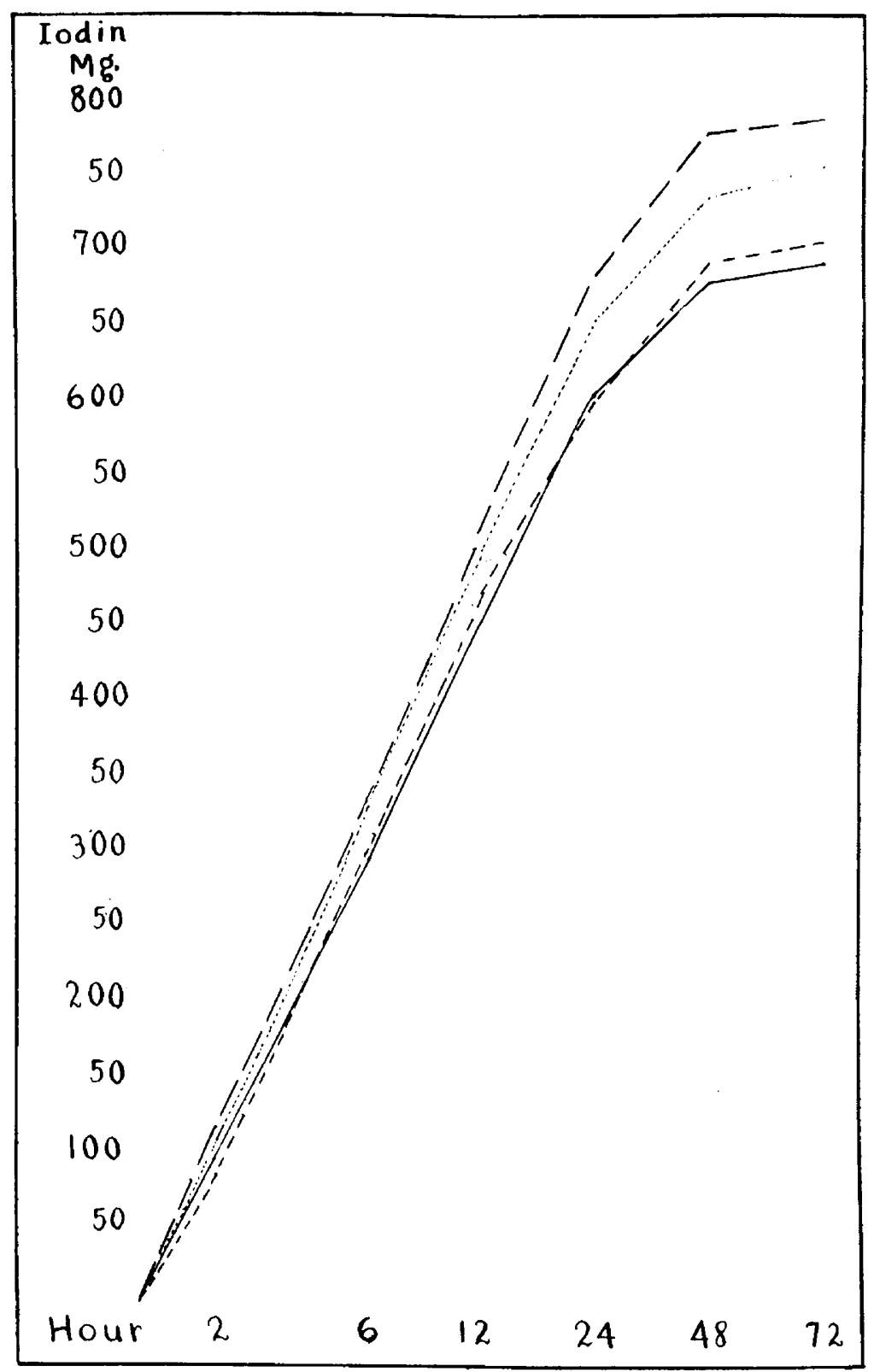

Fig. 2.-Total excretion of jodin in milligrams (Subject $\mathrm{K}$ ) ; sodium iodid; ........ potassium iodid; - - - strontium iodid;..... strontium iodid $\mathrm{x}$ factor. 
greater volume of urine was associated with a greater excretion of iodid, but the reverse was about as frequent. The point is well illustrated in one instance of the potassium series in which the iodin excretion was strikingly uniform at the sixth hour period $(225,212$ and $222 \mathrm{mg}$.) with a marked variation in the urine output $(600,205$ and 270 c.c., respectively). The average volume of urine was practically the same with the different salts.

Subjective Symptoms.-About an hour after taking the iodid two subjects noticed an irritation or soreness of the pharynx which persisted for several hours and disappeared during the afternoon. There was no apparent difference from the different iodids in the time of onset, intensity or duration of the symptoms. No other symptoms were noted. The third subject noted an acne eruption of the same degree from the strontium and sodium salts.

\section{CONCLUSIONS}

The combination of iodin with strontium does not delay the excretion, and therefore the absorption, of iodin over that of sodium and potassium. In fact, both the rate and total excretion seem to be slightly greater with the strontium iodid, although the difference seems immaterial. 